\title{
Morphological and histochemical characterization of the digestive tract of the puffer fish Sphoeroides testudineus (Linnaeus 1758) (Tetraodontiformes: Tetraodontidae)
}

\author{
KAINÃ R.C. FAGUNDES ${ }^{1}$, MATHEUS M. ROTUNDO ${ }^{2}$ and RENATA B. MARI ${ }^{1}$ \\ ${ }^{1}$ Laboratório de Morfologia de Animais Marinhos, Instituto de Biociências, Universidade Estadual Paulista, \\ Campus do Litoral Paulista, Praça Infante Dom Henrique, s/n, 11330-900 São Vicente, SP, Brasil \\ ${ }^{2}$ Acervo de Zoológico, Universidade Santa Cecília, Rua Oswaldo Cruz, 277, 11045-907 \\ Santos, SP, Brasil
}

Manuscript received on March 11, 2015; accepted for publication on August 24, 2015

\begin{abstract}
Morphological analysis of the digestive tract of Sphoeroides testudineus showed an esophagus with an anterior and a posterior portion, the abdominal pouch. No stomach was observed between the abdominal pouch and the intestine. The intestine was arranged in three segments and two loops, and the distal portion had the rectum opening into the anus. Histochemical analyses showed that the esophagus secreted acid mucosecretions, and that there was a qualitative increase in goblet cells from the proximal to distal area of the intestine. The rectum showed cells secreting acid and neutral mucus. Given these features, this species presents a morphology which creates a link between its ecology and behavior.
\end{abstract}

Key words: Tetrodontiformes, digestive system, anatomy, mucosecretion, stomachless fish.

\section{INTRODUCTION}

Fish represent the largest group of vertebrates inhabiting diverse aquatic ecosystems (Lagler et al. 1977). Knowledge on the diet of these animals is a consistent approach to evaluate interactions in aquatic communities, as the food spectrum may be influenced by environmental conditions, such species biology (Winemiller 1989, Hahn et al. 1997).

During the evolutionary process, and according to the feeding habits, fish develop their own mechanisms to gather food and to survive, leading to changes in the morphology of the digestive

Correspondence to: Kainã R.C. Fagundes

E-mail: kainafagundes@gmail.com system caused by feeding behavior (Dzhumaliyev 1982, Fanta et al. 2001). Likewise, morphological limitations may generate different feeding behaviors.

There are structural changes of the digestive tract that take place during ontogenesis and are caused by different functional adaptations, changes in the diets and changes in the environment (Govoni et al. 1986) and morphological data on the digestive system may provide more understanding on species performance in their natural ecosystems or in fish farming, and may provide bioindicators of environmental changes (Castro 2000).

Several descriptive studies have focused on the morpho-physiological characteristics of the intestines of Teleostei and revealed that although 
simpler than that of higher vertebrates, they are widely variable between species because of the diet, phylogeny, and body shape (Kapoor et al. 1975).

Morphological changes in the digestive tract of Teleostei are similar in some species. Species such as the puffer fish present a specialization of the digestive system that allows their body to expand by the intake of water or air (Brainerd 1994, Figueiredo and Menezes 2000). Such feature in this species is a defense mechanism against predators, as puffer fish are not agile swimmers (Myer 1989). Water intake in the proximal portion of the digestive tract enables the expansion of the coelomic cavity, transforming the animal in a rigid sphere with small spikes protruding from the body, and making it difficult to be preyed (Zhao et al. 2010). The puffer fish belongs to two families Tetraodontidae and Diodontidae in the order Tetraodontiformes (Figueiredo and Menezes 2000).

The puffer fish belonging to the family Tetraodontidae present modified jaws constituted by two upper and two lower plates resulting in a powerful bite. Absence of pelvic fins and typical scales, but with thorn-shape projections and sparse dermal appendages in most species. They usually inhabit coastal waters, sometimes enter the estuary, and some of them live in fresh-water. They are, in general, carnivorous and their flesh is appreciated by consumers, but several species contain toxins (Figueiredo and Menezes 2000).

Puffer fish are quite abundant in coastal ecosystems (Yanez-Arancibia et al. 1993, Ferreira and Paiva-Filho 1995, Araújo et al. 1997, 1998, Rodriguez-Romero et al. 1994, Lopes et al. 1999, Sena and Santos 2002), inhabit the tropical and subtropical coastand their distribution is along the west coast of the North Atlantic, from Florida to Brazil (Thayer et al. 1987, Carpenter 2002, Acero and Polanco 2006, Díaz and Gómez-López 2003).

Considering that the puffer fish show the morfology of the digestive tract as a key system in its behavior, in addition to digestive functions, studies conducted in other species of puffer fish have shown such features. Zhao et al. (2010) demonstrated, in Takifugu obscurus, that the posterior portion of the esophagus, in addition to expanding, it also had the function of accommodating food. On the other hand, in an embryological study of the species Sphoeroides annulatus (Jenyns 1842) (Tetraodontidae), García-Gasca et al. (2006) showed that during all the development until the larval stage, the stomach was absent and, due to their evolutionary characteristics, such as the ability to expand their body cavity, the poison and morphological features, they have attracted considerable attention in various fields of Teleostei biological research, such as genetics (Brainerd and Murray 2000, Aparicio et al. 2002, Amores et al. 2004), functional morphology (Brainerd 1994, Turingan et al. 1995, Wainwright et al. 1995, Wainwright and Turingan 1996, Bartol et al. 2003), and comparative anatomy (Britz and Johnson 2005).

Therefore, given the features of the digestive tract acting with the behavior which enable success in their environment and the abundance in Atlantic coast, the objectives of this study were to describe the morphology of the digestive tract of adult specimens of $S$. testudineus in order to identify morphological characteristics that enable them to inflate; to describe the histochemical characteristics of the intestinal mucosa in relation to the feeding habits of these fish; and to compare their morphological characteristics with those of previously studied species of puffer fish from the Tetraodontidae family.

\section{MATERIALS AND METHODS}

All procedures were carried out according to the the ethical principles of animal experimentation adopted by Brazilian College of Animal Experimentation and and approved by the Ethics Committee on Animal Use of the Campus do Litoral Paulista, processo: $011 / 2015$. 
Twenty adult female and male specimens of S. testudineus were used for this study. They were obtained from artisanal fisheries in the coastal region of Santos, São Paulo, Brazil and then transported to the laboratory, meansured, weighed, opened by ventral incision, and fixed with injections of formaldehyde $10 \%$ in the muscle and cavities, and immersed in the same solution for at least 48 hours for complete fixation.

For the analysis of the organs of the digestive, the samples were processed for histological routine and cut in $5-\mu \mathrm{m}$ sections to be analyzed by light microscopy, and then were stained with Hematoxylin and Eosin (HE). They were also stained with Periodic acid-Schiff and Alcian Blue (PAS+AB). PAS was used to evidence neutral mucus secretion, $\mathrm{AB} \mathrm{pH} 0.5$ for gastric secretions, and $\mathrm{AB}$ pH 2.5 for acids in general. Interpretation of the results was based on the staining intensity, as determined by Díaz et al. (2003). Staining intensity ranged from - (no staining) to +++ (intense staining).

\section{RESULTS}

The specimens analyzed were spherical and showed no muscles in the ventral region. The organs in the digestive tract were elongated, different from the shape of the body cavity, and were covered with peritoneum (Figure 1a, b). The average total body length was $22.33 \pm 2.89 \mathrm{~cm}$, and mean length of the digestive tract was $28.65 \pm 3.16 \mathrm{~cm}$; the weight of the specimens was $168.8 \pm 72.12 \mathrm{~g}$.

The cranial region of the digestive tract showed the foregut, formed by the esophagus, with two distinct portions: anterior and posterior one. No pyloric sphincter was observed, suggesting absence of stomach. The midgut presented three segments (proximal, middle, and distal portion). The distal portion was made up by the rectum, which opened into the anus. The liver was well-developed, with the presence of the gall bladder with the bile duct opening into the first intestinal segment (Figure $1 b)$.
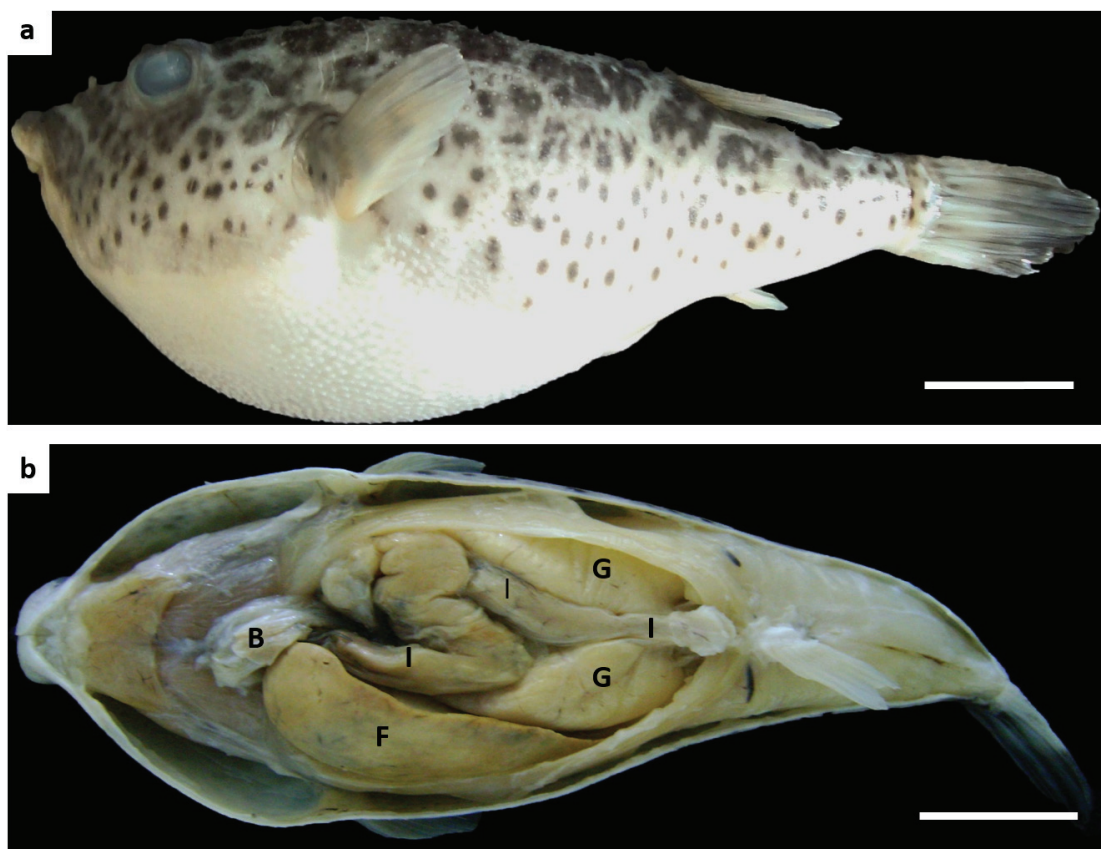

Figure 1 - Overview of Sphoeroides testudineus. - a. Lateral view. - b. Ventral view evidencing the abdominal pouch $(P)$, intestinal tract $(I)$, liver $(L)$, gonads $(G)$, rectum (R). Bar: $0.5 \mathrm{~cm}$. 
The anterior portion of the esophagus was short and tubular, with uniform diameter, and was continuous with the orobranquial cavity. The posterior portion of the esophagus was shaped like a sac and could inflate towards the ventral region. Given the characteristics of this structure, it was called abdominal pouch (Figures 1b, 2a, b).

This abdominal pouch was separated from the midgut by a well-developed esophageal sphincter, which projected into the pouch (Figure 2c). The midgut was attached to the mesentery, which showed two loops and three segments. The first intestinal segment extended caudally from the esophageal sphincter to the gonads, forming the first intestinal loop; the second intestinal segment extended cranially towards the abdominal pouch, forming the second loop; and the third intestinal segment extended caudally, in a straight line, ending in the rectum, which opened into the anus (Figure 2a, b). Mesoscopic analysis showed that the intestinal mucosa presented longitudinal folds from the esophageal sphincter to the end of the intestinal tract. The rectal sphincter separated the intestinal tract from the rectum and this final sphincter was less developed than the esophageal one.

Stratigraphy of the digestive tract showed the four basic layers: mucosa, submucosa, tunica muscularis, and serosa. There was no evidence of glands in the submucosal layer, and there were two layers in the tunica muscularis, an inner circular one and an outer longitudinal one.

The mucosa of the anterior portion of the esophagus showed stratified squamous epithelium and the presence of globular glands secreting acid mucus (Table I). The submucosa presented well-vascularized, dense connective tissue, which protruded towards the mucosal folds of the lumen, forming a lamina propria made up of loose connective tissue (Figures 3a, c, 5a).

The abdominal pouch showed a mucosa consisting of stratified squamous epithelium, globular glands secreting acid mucus (Table I), and a thick external muscle layer (Figures 3b, d, 5b). No taste buds were observed on either portions of the esophagus.

The intestinal mucosa showed simple columnar epithelium, which was rich in goblet cells. The

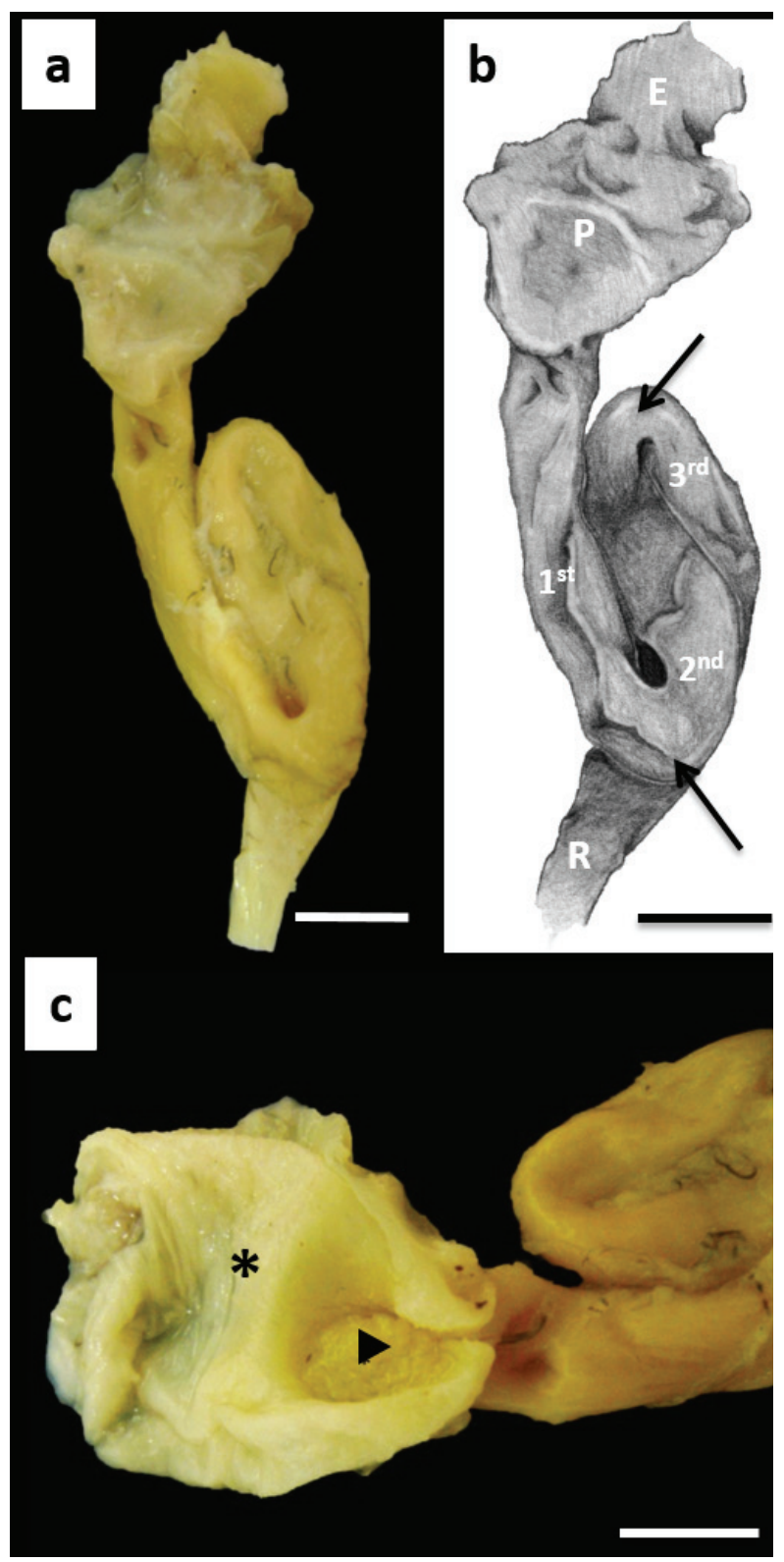

Figure 2 - Composition of the digestive tract of Sphoeroides testudineus. - $\mathbf{a}$ and $\mathbf{b}$. Scheme of the digestive tract showing the esophagus (E), abdominal pouch (P), intestinal segments $\left(1^{\text {st }}, 2^{\text {nd }}\right.$ and $3^{\text {rd }}$ ) evidencing the intestinal loop (arrows), rectum (R). - c. Inside view of the abdominal pouch showing the esophageal sphincter (arrowhead) and the mucosa of the pouch (asterisk). Bar: $1.0 \mathrm{~cm}$. 
TABLE I

Reaction intensity histochemical rating of PAS and $\mathrm{AB}$ pH 0.5 and 2.5 of the mucosa of the segments of the digestive tract of puffer fish Sphoeroides testudineus.

\begin{tabular}{ccccccc}
\hline Histochemical staining & \multicolumn{6}{c}{ Segments of the Digestive Tract } \\
\hline & $\begin{array}{c}\text { Anterior } \\
\text { Esophagus }\end{array}$ & $\begin{array}{c}\text { Posterior } \\
\text { Esophagus }\end{array}$ & $\begin{array}{c}1^{\text {st }} \text { Intestinal } \\
\text { Segment }\end{array}$ & $\begin{array}{c}2^{\text {nd }} \text { Intestinal } \\
\text { Segment }\end{array}$ & $\begin{array}{c}3^{\text {rd }} \text { Intestinal } \\
\text { Segment }\end{array}$ & \multirow{2}{*}{ Rectum } \\
\hline PAS & + & + & + & + & +++ & +++ \\
\hline $\mathrm{AB} \mathrm{pH} 0.5$ & ++ & +++ & - & + & + & + \\
\hline $\mathrm{AB} \mathrm{pH} 2.5$ & +++ & +++ & + & +++ & ++ & + \\
\hline
\end{tabular}
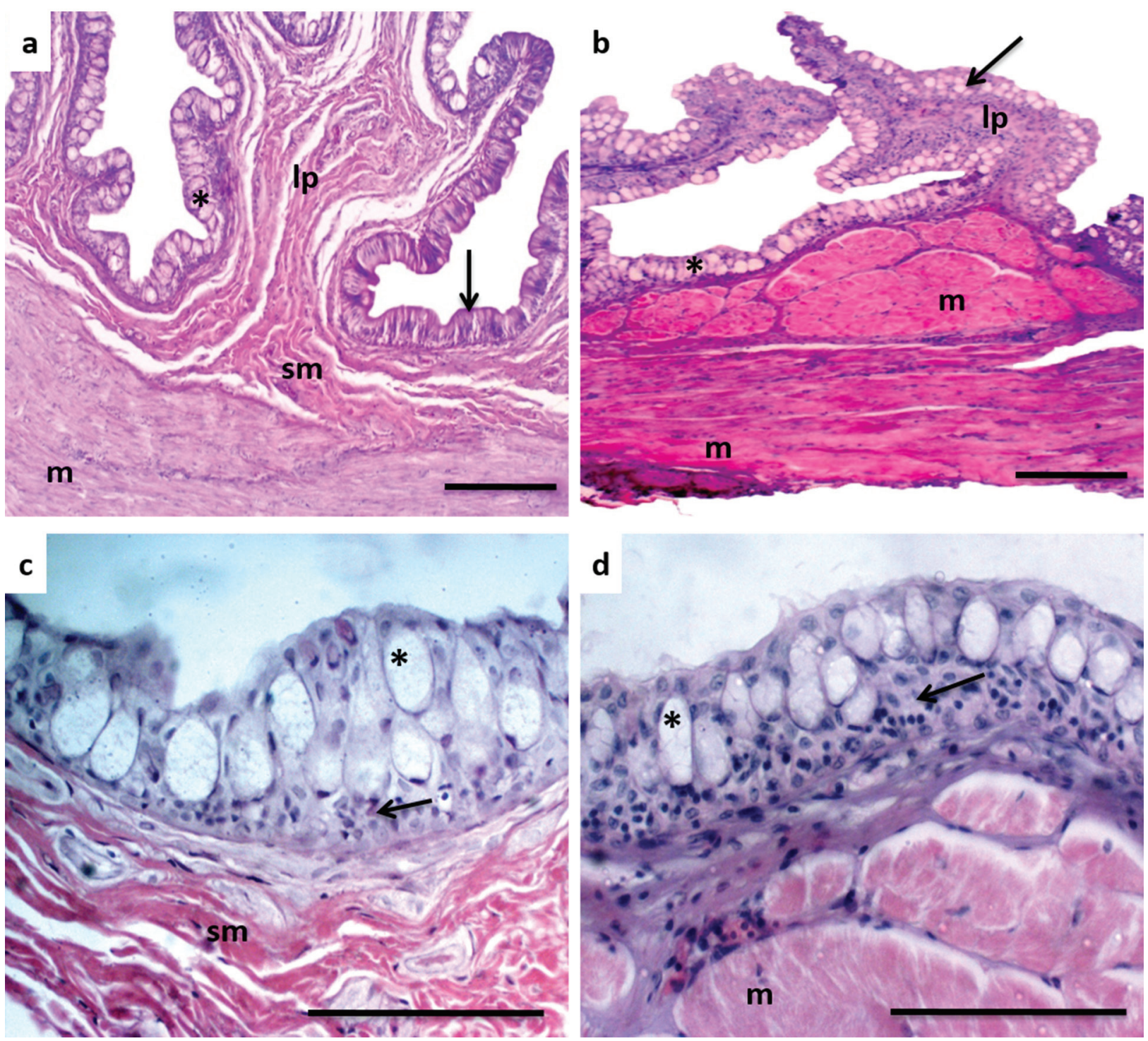

Figure 3 - Stratigraphy of esophagus of Sphoeroides testudineus. - a. Anterior portion of esophagus. HE. - b. Posterior portion of esophagus (abdominal pouch). HE. Bar.: $100 \mu \mathrm{m}$. - c. High magnification of anterior esophagus showing the stratified squamous epithelium (arrow). HE. - d. High magnification of posterior portion of esophagus (abdominal pouch) with stratified squamous epithelium (arrow). HE. Bar.: $100 \mu \mathrm{m}$. Mucosa rich in globular unicellular mucous glands (*), lamina propria (lp), submucosa (sm), muscular layer (m). 
intestinal villi were made up of loose connective tissue. The tunica muscularis presented smooth muscle, with the myenteric plexus between the circular and longitudinal layers. Mucous secretions of goblet cells was histochemically different in the various intestinal segments (Table I), and a qualitative distal increase in goblet cells was observed (Figures $4 \mathrm{a}, 5 \mathrm{c}-\mathrm{e}$ ). In the dissection of the fish, it was observed that the liver was located on the left latero-ventral region, and the bile duct opened into the first intestinal segment. No pancreas was observed.

The mucosa of the rectum presented simple columnar epithelium, and the morphology of the glands was similar to that of the esophagus, with neutral mucus secretion (Table I; Figures 4b, 5f).

\section{DISCUSSION}

The puffer fish $S$. testudineus has the ability to inflate its abdominal pouch and body cavity by the intake of water or air, becoming a rigid sphere. Such characteristics have been observed in other species of puffer fish, such as Takifugu obscurus (Abe 1949) (Tetraodontidae) (Zhao et al. 2010).
Zhao et al. (2010) observed the presence of loose connective tissue lining the organs and changing the shape of the backbone, and the existence of an abdominal pouch which was observed in $S$. testudineus. Chi-Espínola and Vega-Cendejas (2013) observed that the feeding habits of $S$. testudineus are mostly based on bivalves $(68.33 \%)$, gastropods (59.95\%) and macrophyte (50.78\%), as percentages of the Index of Relative Importance (IRI). These feeding habits are different from other species of Tetraodontidae, such as T. obscurus, which mainly feed on small crustaceans (Chen and Yang 2005), as seen in Takifugu ocellatus (Linnaeus 1758) (Chen and Yang 2005). When small crustaceans are eaten, they are swallowed in one piece, and $S$. testudineus needs mucosa rich in mucous glands and a thick layer of connective tissue in the submucosa to better accommodate the carapace of the prey.

An esophageal mucosa that is rich in glands is not particularly common in this family, but it is the pattern observed in Teleostei fish, covering a wide range of feeding habits. Such as for the omnivorous species Pterodoras granulosus (Valenciennes 1821), which show many mucous glands mainly
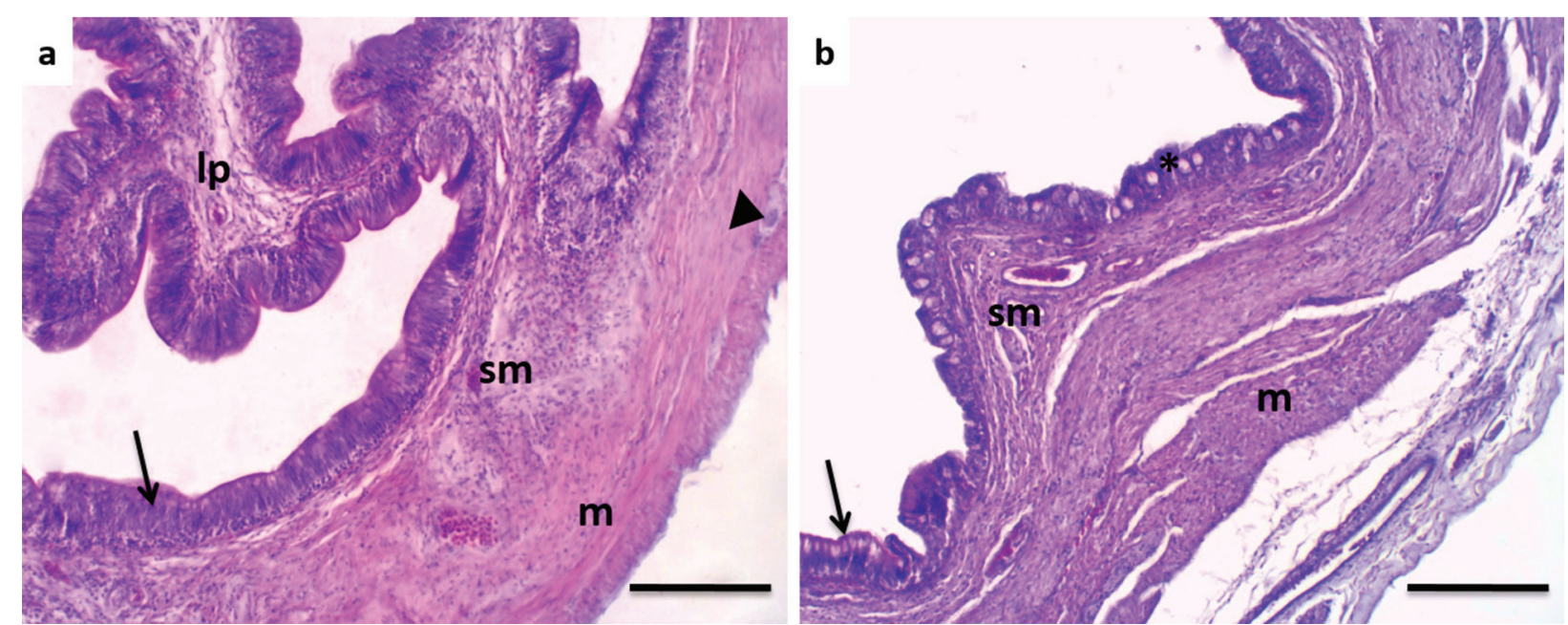

Figure 4 - Stratigraphy of intestinal tract of Sphoeroides testudineus. - a. Intestine showing mucosa with simple columnar epithelium (arrow) and myenteric plexus between the circular and longitudinal muscular layer (arrow-head). HE. - b. Rectum. Mucosa with simple columnar epithelium (arrow). Mucosa rich in globular unicellular mucous glands (*), lamina propria (lp), submucosa (sm), muscular layer (m). HE. Bar.: $100 \mu \mathrm{m}$. 

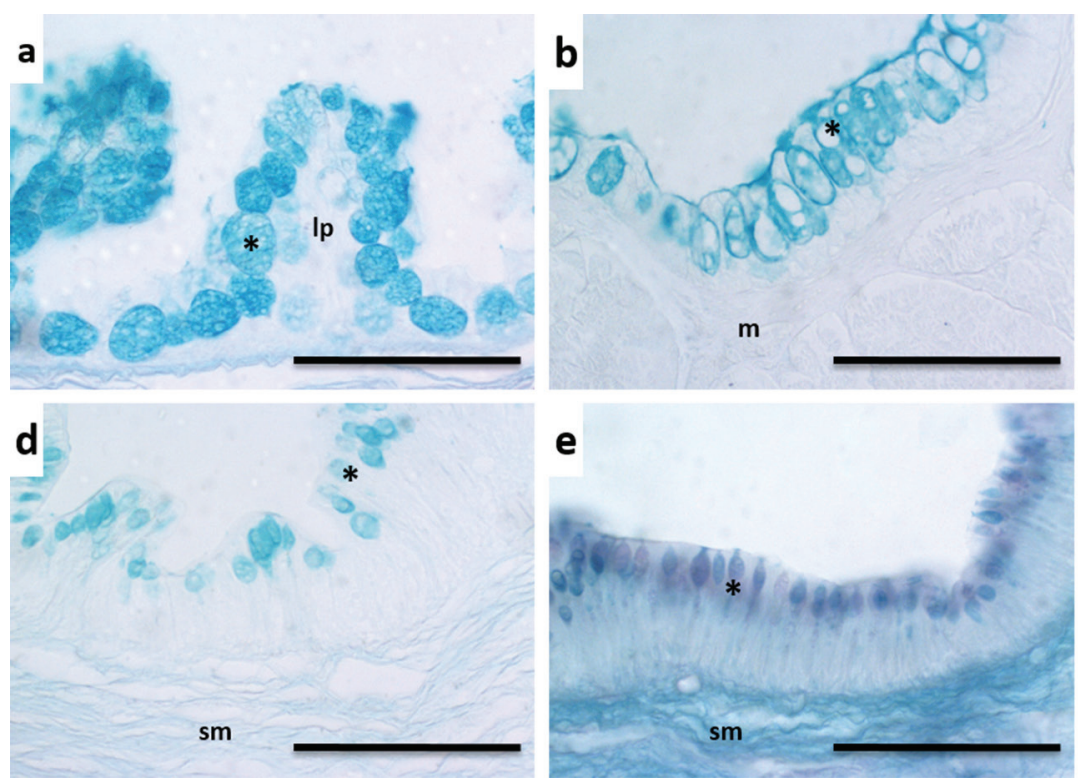
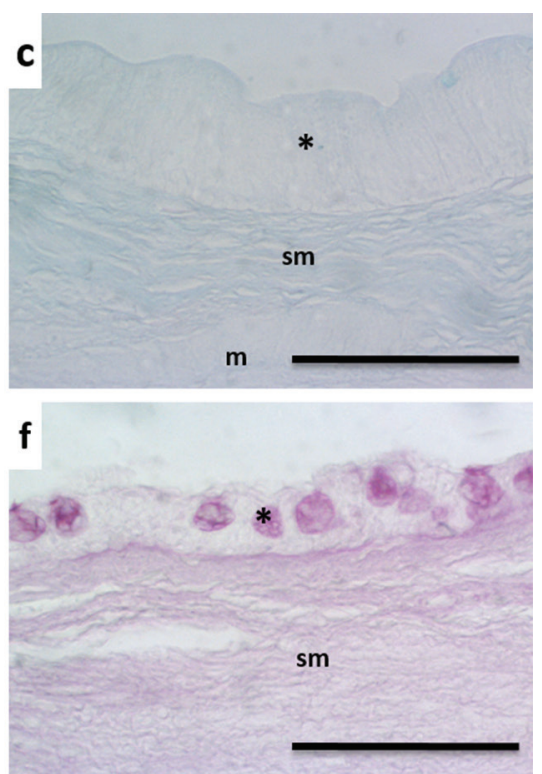

Figure 5 - Histochemical composition of glycoconjugates secreted by mucous glands of Sphoeroides testudineus. - a. Mucosa of the anteior portion of the esophagus evidencing the glands Alcian Blue-postive at pH $0.5(*)$. PAS / AB 0.5. - b. Mucosa of the posterior portion of the esophagus showing glands Alcian Blue-postive at $\mathrm{pH} 0.5$ (*). PAS / AB 0.5. - c. First intestinal segment with no reaction to PAS and AB. PAS / AB 0.5. - d. Second intestinal segment with goblet cells positive for Alcian Blue at $\mathrm{pH} 2.5$ (*). PAS / AB 2.5. - e. Third intestinal segment rich in PAS-positive goblet cells and Alcian Blue at pH 2.5 (*). PAS / AB 2.5. - f. Rectum evidencing mucosa with PAS-postive unicellular globular glands (*). PAS. Lamina propria (lp), submucosa (sm), muscular layer (m). Bar: $100 \mu \mathrm{m}$.

in the esophagus (Germano et al. 2013). This study demonstrates that abundant mucous glands are common in Teleostei. However, the histochemical nature of these glands may be specific to the feeding habits and morphology of the digestive tract of these fish. The abundance of these mucous glands and the histochemical variety of glycoconjugates are also due to the absence of salivary glands. This mucus may increase the lubrication of the food in the esophageal mucosa between the orobranquial cavity and the intestinal tract (Mittal et al. 1994, 1995), as mucus also plays a role in protecting the mucosa both from mechanical injury and bacterial action (Humbert et al. 1984).

Given the absence of stomach and gastric glands, the mucus-secreting glands of the abdominal pouch were modified for chemical digestion of food. This change may explain the low reactivity to PAS in the abdominal pouch, the high reactivity to $\mathrm{AB}$ pH 2.5 and, especially, the high reactivity to
pH 0.5 that was observed in S. testudineus. This staining pattern was different from that obtained in other Teleostei, which usually showed neutral mucus-secreting glands in the esophagus, as demonstrated by Sarasquete et al. (1998) and Díaz et al. (2001). The acid glycoconjugates found in the mucous glands of the esophagus may have some relationship with the desalination of ingested seawater and with the osmoregulatory role of the esophagus (Spicer and Schulte 1992).

The absence of the stomach was based on the finding of only one sphincter, the esophageal one. The stomach is only classified as a true organ if there are two distinct histological regions: the cardia (anterior) and the pyloric region (posterior), both provided with gastric glands (Dalela 1969, Yadav and Sigh 1980, Rombout and Taverne-Thiele 1982, Ulibarrie 1982, Martin and Blaber 1984, Murray et al. 1994). The digestive tract of Teleostei presents several anatomical changes, and one of them is the 
absence of the stomach, which is a well-known feature in other fish families, such as Cyprinidae, Labridae, Gobiidae, Scaridae, Cyprinodontidae, and some of the Poeciliidae (Genten et al. 2009).

The esophageal mucosa presented to be composed of the same type of epithelium, but the posterior portion showed the ability to expand, thus being a continuation of the anterior esophagus, because of this, the esophagus is separated into two portions, the anterior one and the posterior one (abdominal pouch).

The presence of an esophageal sphincter separating the abdominal pouch from the intestinal tract was also observed in another species of stomachless fish, Tautogolabrus adspersus (Walbaum 1792), whose digestive tract morphology was described by Chao (1973). This author demonstrated that the function of this sphincter was to create a transition between the esophagus and the intestines, which was quite different in S. testudineus.

The intestine of $S$. testudineus showed to be morphologically very similar to that of other Teleostei, with absorptive cells, goblet cells, and mucosa made up of simple columnar epithelium (Mohsin 1962, Stabille et al. 1998). In the first intestinal segment of $S$. testudineus, there were few cells secreting acid or basic mucus, and this finding suggests that this is the site of enzymatic digestion. The absence of pancreas in teleosts, as observed for $S$. testudineus, is widely reported. Studies have demonstrated that pancreatic cells are normally found in the liver and secrete their hormones along with liver secretions in the first portion of the intestines, as occurs in S. testudineus, which showed the bile duct opening into the first intestinal segment. Pancreatic cells may also be spread in the first portion of the intestines, as occurs in Barbus conchonius (F. Hamilton 1822) (Rombout and Taverne-Thiele 1982), another stomachless fish.

The abundance of AB-positive mucous secretions in the second intestinal segment indicates intense chemical action related to the intake of food rich in chitinous shells. On the other hand, the third segment showed abundance of PAS-positive mucus-secreting cells, enabling the conduction of the feces, which may contain remnants of exoskeleton, towards the anus opening without causing damage to the intestinal mucosa.

The morphology of the digestive tract of the puffer fish $S$. testudineus proved that this fish is morphologically adapted to expanding its body cavity. It was observed that the absence of the stomach is counterbalanced by digestion of food in the abdominal pouch and in the second intestinal segment, as well as by feeding habits that require increased action of acid mucus, as this fish feeds on foods from estuaries that are coated with calcareous shells. Relationships like these demonstrate the high efficiency and adaptation of this animal to the environment in which it lives and to its ecology.

\section{ACKNOWLEDGMENTS}

The authors are grateful to the Fundação de Amparo à Pesquisa de São Paulo (FAPESP) for the financial support (Processes: 2013/02777-2 and 2012/17482-5).

\section{RESUMO}

A análise morfológica do trato digestório de Sphoeroides testudineus mostrou um esôfago com uma porção anterior e posterior, a bolsa abdominal. Não foi observado estômago entre a bolsa abdominal e o intestino. O intestino estava organizado em três segmentos e duas alças, e a porção distal tinha a abertura do reto para o ânus. Análises histoquímicas mostraram que o esôfago secretou muco secreções ácidas, e que houve um aumento qualitativo nas células caliciformes de proximal para a área distal do intestino. $\mathrm{O}$ reto apresentou células secretoras de muco ácido e neutro. Dadas essas características, essa espécie apresenta um morfologia que cria uma ligação entre a sua ecologia e comportamento.

Palavras-chave: Tetraodontiformes, sistema digestório, anatomia, mucosecreção, peixe sem estômago. 


\section{REFERENCES}

ACERO A AND POLANCO A. 2006. Peces del orden Tetraodontiformes de Colombia. Biota Colombiana 7: 155-164.

AMORES A, SUZUKI T AND YAN YL. 2004. Developmental roles of pufferfish Hox clusters and genome evolution in ray-fin fish. Genome Res 14: 1-10.

APARICIO S, CHAPMAN J AND STUPKA E. 2002. Wholegenome shotgun assembly and analysis of the genome of Fugu rubripes. Science 297: 1301-1310.

ARAÚJO FG, CRUZ-FILHO AG, AZEVEDO MCC AND SANTOS ACA. 1998. Estrutura da comunidade de peixes demersais da Baía da Sepertiba, RJ. Rev Bras de Biol 58(3): 417-430.

Araújo FG, Cruz-Filho AG, AZEVEdo MCC, SANTos ACA AND FERNANDES LAM. 1997. Estrutura da comunidade de peixes jovens da margem continental da Baía de Serpetiba. Acta Biol Leopold 19: 61-83.

BARTOL IK, GHARIB M, WheIHS D, WEBB PW, HOVE JR AND GORDON MS. 2003. Hydrodynamic stability of swimming in ostraciid fishes: Role of the carapace in the smooth trunkfish Lactophrys triqueter (Teleostei: Ostraciidae). J Exp Biol 206: 725-744.

BRAINERD EL. 1994. Pufferfish inflation - functional-morphology of postcranial structures in Diodon holocanthus (Tetraodontiformes). J Morphol 220: 243-261.

BRAINERD EL AND MURRAY SS. 2000. Patterns of genome size evolution in tetraodontiform fishes. Amer Zool 40: 953.

BRITZ R AND JOHNSON G D. 2005. Leis' conundrum: Homology of the clavus of the ocean sunfishes. 1. Ontogeny of the median fins and axial skeleton of Monotrete leiurus (Teleostei, Tetraodontiformes, Tetraodontidae). J Morphol 266: 1-10.

CARPENTER KE. 2002. The living marine resources of the Western Central Atlantic FAO. Species Identification Guide for Fishery Purposes. Amer. Soc. Ichthyol. Herp. Rome. Vol 1, Special Publication No. 5.

CAstro PMG. 2000. Estrutura e dinâmica da frota de parelhas do Estado de São Paulo e aspectos biológicos dos principais recursos pesqueiros demersais costeiros da região sudeste/sul do Brasil $\left(23^{\circ}-29^{\circ} \mathrm{S}\right)$. São Paulo, 261 p. (Tese de Doutorado, Universidade de São Paulo).

CHAO LN. 1973. Digestive system and feeding habits of the cunner, Tautogolabrus adspersus, a stomachless fish. Fish Bull 71: 565-586.

CHEN Y AND YANG Z. 2005. Diets of obscure puffer (Takifugu obscurus) and ocellated puffer (Takifugu ocellatus) during spawning migration. J Fresh Ecol 20(1): 195-196.

CHÍ-EsPínOlA AA AND VEGA-CENDEJAS ME. 2013. Hábitos alimentícios de Sphoeroides testudineus (Perciformes: Tetraodontidae) en el sistema lagunas de Ría Lagartos, Yucatán, México. Rev Biol Trop 61(2): 849-858.

DALELA RC. 1969. Morpho-histology studies of the alimentary tract in the mastocumbelid eel Macrognathus aculeatus. J Zool Soc 21: 117-128.
DÍAZ AO, GARCÍA AM, DEVINCENTI CV AND GOLDEMBERG AL. 2001. Mucous cells in Micropogonias furnieri gills: histochemistry and ultrastructure. Anat, Hist, Embr. 30: 135-139.

DÍAZ AO, GARCÍA AM, DEVINCENTI CV AND GOLDEMBERG AL. 2003. Morphological and Histochemical Characterization of the Mucosa of the digestive tract in Engraulis anchoita (Hubbs and Marini, 1935). Blackwell Verlag 30: 135-139.

DÍAZ JM AND GÓMEZ-LÓPEZ DI. 2003. Cambios históricos en la distribución y abundancia de praderas de pastos marinos en la bahía de Cartagena y áreas aledañas (Colombia). Bol Invest Mar Cost 32: 57-74.

DZHUMALIYEV MK. 1982. The structure of the epithelium in fishes from different taxonomic groups. Biol Nauki, Kazakh 1: 65-75.

FANTA E, Rios FSA, MEYER AA, GROTZNER SR AND ZALESKI T. 2001. Chemical and visual sensory systems in feeding behavior of the antartic fish Opthalmolycus amberensis (Zoarcidae). Antart rec 45(1): 27-42.

FERREIRA LI AND PAIVA-FILHO AM. 1995. Estudo sobre baiacus da região estuarina-lagunar de Cananéia, SP. In: Sociedade Brasileira de Ictiologia, Resumos do XI Encontro Brasileiro de Ictiologia, Campinas.

FigueIREDO JL AND MENEZES NA. 2000. Manual de peixes marinhos do Sudeste do Brasil. São Paulo: Museu de Zoologia/USP.

GARCÍA-GASCA A, GALAVIZ MA, GUTIÉRREZ JN AND GARCÍA-ORTEGA A. 2006. Development of the digestive tract, trypsin activity and gene expression in eggs and larvae of the bullseye puffer fish Sphoeroides annulatus. Aquac 251: 366-376.

GENTEN F, TERWINGHE E AND DANGUY A. 2009. A Atlas of fish histology. Sci Publis. Belgium.

Germano RM, Stabille, SR, MARi RB, PEREIRA JNB, FAGLIONI JRS AND NETO MHM. 2013. Morphological characteristics of the Pterodoras granulosus digestive tube (Valenciennes, 1821) (Osteichthyes, Doradidae). Acta Zool, p. 1-10.

Govoni JJ, BOEHLERT GW AND WATANABE Y. 1986. The physyology of digestion in fish larvae. Environ Biol Fish 16(1-3): 59-77.

HAHN NS, AGOSTINHO AA, THOMAZ SM AND NAKATANI K. 1997. Ecologia trófica. In: Vazzoler AEAM et al. (Eds), A planície de inundação do alto rio Paraná: aspectos físicos, biológicos e socioeconômicos. Maringá: EDUEM, p. 209228.

HUMBERT W, KIRSCH R AND MEISTER MF. 1984. Scanning electron microscopic study of the esophageal mucous layer in the eel, Anguilla anguilla L. J Fish Biol 25: 117-122.

KAPOOR R, SMITH H AND VERIGHINIA IA. 1975. The alimentary canal and digestion in teleosts. Advan in Mar Biol 13: 109-239. 
LAGLER KF, BARDACH JE, MILLER RR AND PASSINO DRM. 1997. Ichthyology, p. 506, $2^{\text {a }}$ ed., John Wiley and Sons.

LOPES PRD, OLIVEIRA-SILVA JT, SENA MP, SILVA IS, VEIGA DCM, SILVA GR AND SANTOS RCI. 1999. Contribuição ao conhecimento da ictiofauna da Praia de Itapema, Santo Amaro da Purificação, Baía de Todos os Santos, Bahia. Acta Biol Leopold 21(1): 99-105.

MARTIN TJ AND BLABER SJM. 1984. Morphology and histology of the alimentary tracts of Ambassidae (Cuvier) (Teleostei) in relation to feeding. J Morphol 182: 295-305.

MitTAL AK, UEDA T, FUJIMORI O AND YAMADA K. 1994. Histochemical analysis of glycoproteins in the unicellular glands in the epidermis of an Indian freshwater fish Mastacembelus pancalus (Hamilton). Histochem J 26: 666-777.

MitTAL AK, UEDA T, FUJimORI O AND YAMADA K. 1995. Carbohydrates in the epidermal mucous cells of a freshwater fish Mastacembelus pancalus (Mastacembelidae, Pisces) as studied by electron-microscopic cytochemical methods. Cell Tissue Res 280: 531-539.

MOHSIN SM. 1962. Comparative morphology and histology of the alimentary canal in certain groups of Indian teleosts. Acta Zool 43: 79-133.

MUrray HM, Wright GM AND GOFF GP. 1994. A comparative histological and histochemical study of the stomach from three species of pleuronectid, the Atlantic halibut, Hippoglossus hippoglossus, the yellowtail flounder, Pleuronectes ferruginea, and the winter tlounder, Pleuronecles americanus. Can J Zool 72: 1199-1210.

MYER RF. 1989. Micronesian reef fishes. Coral Graphics. Commerce, Wellington. 32. (Reports).

RODRIGUEZ-ROMERO J, ABITIA-CARDEANAS LA, GALVANMAGAÑA F AND CHAVES-RAMOS H. 1994. Composicion, abundancia y riqueza específica de La ictiofauna de Baia Conception, Baja Califórnia sur, México. Ciênc Marin 20(3): 321-350.

Rombout JKWM AND TAVERNE-THIELE JJ. 1982. An immunocytochemical and electron-microscopical study of endocrine cells in the gut and pancreas of a stomachless teleost fish, Barbus conchonius (Cyprinidae). Cell Tissue Res 227: 577-593.
SARAsquete C, GONZÁlez, ML, Arellano JM, PÉreZPRIETO S, GARCÍZ ER AND BORREGO JJ. 1998. Histochemical study of lymphocystis disease in skin of gilthead seabream, Sparus aurata from the southatlantic coasts of Spain. Histol Histopathol 13: 37-45.

SENA MP AND SANTOS ACA. 2002. Distribuição e recrutamento de baiacus (Actnopterygii, Tetraodontiformes) na margem oeste da Baía de Todos os Santos, Bahia. Acta Biol Leopold 24(1): 81-93.

SPICER SS AND SCHULTE BA. 1992. Diversity of cell glycoconjugates shown histochemically: a perspective. J Histochem Cytochem 40: 1-38.

STABILLE SR, GERMANO RM, MIZUNO MS AND RIBEIRO EA. 1998. Características morfológicas gerais da estratigrafia do bulbo intestinal e do intestino de Cyprinus carpio (Linnaeus, 1758) (Osteichthyes- Cyprinidae). Arq Ciên Saúde da UNIPAR 2: 155-161.

THAYER GW, COLBY DR AND HeTtLER WF JR. 1987. Utilization of the red mangrove prop root habitat by fishes in south Florida. Mar Ecol Prog Ser 35: 25-38.

ULIBARRIE LS. 1982. Histoquimica de las mucinas epiteliais gastrointestinais de Serrasallmus spinopleura (Pisces, Characidae). Nat Assoc Res Sci 13: 1-4.

WAINWRIGHT PC AND TURINGAN RG. 1996. Muscular basis of buccal pressure: Inflation behavior in the striped burrfish Chilomycterus schoepfi. J Exp Biol 199: 1209-1218.

WAINWRIGHT PC, TURINGAN RG AND BRAINERD EL. 1995. Functional morphology of pufferfish inflation: Mechanism of the buccal pump. Copeia 3: 614-625.

WINEMILLER KO. 1989. Ontogenetic diet shifts and resource partitioning among piscivorous fishes in the Venezuelan llanos. Environ Biol Fish 26: 177-199.

YADAV AN AND SINGH BR. 1980. The gut of an intestinal air-breathing fish, Lepidocephalus guntea (Ham.). Arch Biol 91: 413-422.

YANEZ-ARANCIBIA A, DOMINGUEZ AL AND DAY JW. 1993. Interactions between mangroves and seagrass habitats mediated by estuarine nekton assemblages - coupling of primary and secondary production. Hydrobiol 264: 1-12.

ZHAO S, SONG JK AND WANG XJ. 2010. Functional morphology of puffing behavior in pufferfish (Takifugu obscurus). Zoo Res 31(5): 539-549. 